\title{
The Effect of Plasma Spraying on the Microstructure and Aging Kinetics of the Al-Si Matrix Alloy and Al-Si/SiC Composites
}

\author{
Yahya Altunpak, Hatem Akbulut, and Fatih Üstel
}

(Submitted February 14, 2009; in revised form March 24, 2009)

\begin{abstract}
The Al-Si (LM 13)-based matrix alloy reinforced with $\mathrm{SiC}$ particles containing 10, 20, and 30 vol.\% $\mathrm{SiC}$ particles were spray-formed onto Al-Si substrates. The sprayed samples were directly subjected to a standard aging treatment (T551). From the experiments, it was observed that the high rate of solidification resulted in very fine silicon particles which were observed as continuous islands in the matrix and each island exhibited several very fine silicon crystals. Analysis showed that plasma-spraying caused an increased solid solubility of the silicon in the aluminum matrix. DSC measurements in the permanent moldcast Al-Si matrix alloy and plasma-sprayed Al-Si matrix alloy showed that plasma-spraying causes an increase in the amount of GP-zone formation owing to the very high rate solidification after plasmaspraying. In the plasma-sprayed $\mathrm{Al}-\mathrm{Si} / \mathrm{SiC}$ composites $\mathrm{GP}$ zones were suppressed, since particle-matrix interfaces act as a sink for vacancies during quenching from high plasma process temperature. Introduction of $\mathrm{SiC}$ particles to the $\mathrm{Al}-\mathrm{Si}$ age-hardenable alloy resulted in a decrease in the time required to reach plateau matrix hardness owing to acceleration of aging kinetics by ceramic SiC particles.
\end{abstract}

Keywords aging kinetics, MMCs, plasma spraying, wear

\section{Introduction}

Composite materials can bring the combined advantages of both reinforcement and matrix materials into full play, which gives us quite a high degree of freedom in material design. The study of composite materials has, therefore, become one of the frontiers in materials science research, especially the study of metal matrix or intermetallics matrix composites (Ref 1). There are, however, problems associated with the application of conventional processing techniques for metal matrix composites (MMCs). Among them, the compatibility between the reinforcement and the matrix is often cited as a chief concern. There are a number of production methods for MMCs, and each of these methods has certain advantages coupled with disadvantages. The oldest method of manufacturing is the powder metallurgy route. This has all the advantages of a well-known and mature technology, but it is relatively expensive because of the large number of steps in the overall process. Two further disadvantages are the possibility of segregation of powder because of density or size differences, and the fact that many desirable combinations are not possible (Ref 2). Melt-processing is an alternative and attractive procedure in certain cases. This method is simple and cheap when compared with other

Yahya Altunpak, Gerede Vocational School of Higher Education, Abant Izzet Baysal University, 14900 Bolu, Turkey; and Hatem Akbulut and Fatih Üstel, Department of Metallurgical and Materials Engineering, Engineering Faculty, Sakarya University, Esentepe Campus, 54187 Sakarya, Turkey. Contact e-mail: yaltunpak@yahoo.com. manufacturing processes. This method is only applied to certain systems where long contact times at high temperatures can be tolerated without deterioration of the composite (Ref 3). Plasma-spraying of the metal and ceramic powder mixtures is an alternative new MMC production technique for elimination of the deleterious effect of the interface phases. Gui and co-workers (Ref 4-6) studied different series of the SiCpreinforced aluminum composites with plasma-spraying process. They pointed out that no reaction products or oxidation were observed in the resultant composite materials. They also reported that such composites are good candidates for electronic packaging, wear and high temperature applications.

In this study, Al-Si matrix alloy containing $\mathrm{SiC}$ particles is intended to coat a monolithic Al-Si matrix alloy substrate by plasma-spraying technique to eliminate the liquid-SiC interaction time and to obtain a thick layer with good wear resistance and homogenous particle distribution.

\section{Experimental Details}

The Al-Si/SiC composites were produced by a thermal plasma-spraying process as thick composite films. Plasmasprayed matrix was an $\mathrm{Al}-12 \mathrm{wt} . \% \mathrm{Si}, 1.2 \mathrm{wt} . \% \mathrm{Cu}, 0.9$ wt. $\% \mathrm{Mg}$ Al-Si matrix alloy powder. Matrix alloy powders with a grain size range between 30 and $50 \mu \mathrm{m}$ were mechanically mixed with 10,20 , and 30 vol. $\%$ SiC powders so that the particle size range was between 30 and $40 \mu \mathrm{m}$. The mechanically mixed unreinforced Al-Si and composite powders were sprayed onto a Al-Si matrix alloy substrate (chemical composition by wt.\%: 12 $\mathrm{Si}, 1.16 \mathrm{Cu}, 1.21 \mathrm{Mg}, 0.9 \mathrm{Ni}, 0.17 \mathrm{Zn}, 0.12 \mathrm{Mn}, 0.48 \mathrm{Fe}$, balance $\mathrm{Al}$ ) with planar geometry in air using a Metco plasmaspray gun with $\mathrm{Ar}-\mathrm{H}_{2}$ plasma. The $\mathrm{Al}-\mathrm{Si}$ powders and the 
Al-Si/SiC mixtures were formed by injection of a mixture of aluminum-silicon alloy and $\mathrm{SiC}$ particle powders into the hot plasma zone ( 8000 to $12,000{ }^{\circ} \mathrm{C}$ ) of an $\mathrm{Ar}-\mathrm{H}_{2}$ thermal plasma jet.

Although the jet can be extremely hot, powder-injection parameters and residence time inside the jet were controlled so that only the Al-Si alloy powder would melt. This selective melting was controlled by adjustment of the current at $500 \mathrm{~A}$, voltage between anode and cathode 60 to $70 \mathrm{~V}$, and $\mathrm{H}_{2}$ and $\mathrm{Ar}$ flow rates 10 and $60 \mathrm{sccm}$, respectively. The ceramic particles remained in solid state and no melted SiC particle was detected after the spraying process. After the plasma-spray deposition process, the samples were directly subjected to a standard aging treatment (T551) up to $60 \mathrm{~h}$ at $204{ }^{\circ} \mathrm{C}$. A standard gravity-cast Al-Si matrix alloy was also produced for the comparison of the aging characteristics with the plasma-sprayed Al-Si matrix alloy. For gravity-cast unreinforced alloy a permanent cast iron mold, which was heated up to $150{ }^{\circ} \mathrm{C}$, was used and the melt superheated to $700{ }^{\circ} \mathrm{C}$ prior to casting. After the casting process, the mold was water-quenched. Porosity and the amount of the retained $\mathrm{SiC}$ particles of the coatings were measured by means of a line-intercept method with an optical microscope equipped with an image analysis system.

Microhardness measurements were carried out with a LECO M-400 microhardness tester. A micro-Vickers microhardness indenter was used to provide indentation depths in the sprayed layers. A $50 \mathrm{~g}$ load was applied for $15 \mathrm{~s}$ to measure the hardness. Optical microscopy, scanning electron microscopy (SEM), and x-ray analysis were carried out for both as-sprayed and as-cast specimens. Energy dispersive spectroscopy (EDS) analysis was performed from $\mathrm{Si}$ and $\mathrm{SiC}$-free regions in a Cambridge Ins. Stereoscan SEM attached to a 360 Noran EDS energy dispersive spectroscopy facility. Analysis was carried out in both the unreinforced gravity-cast Al-Si matrix alloy and plasma-sprayed matrix materials. Plasma-sprayed materials and the gravity-cast Al-Si matrix alloys were immediately stored in a $-15{ }^{\circ} \mathrm{C}$ refrigerator after production of the materials. Discs (5 $\mathrm{mm}$ diameter and $0.3 \mathrm{~mm}$ thickness) for differential scanning calorimetry (DSC) were polished and weighed. The DSC analysis of rapid-quenched matrix alloy and composites were carried out with a Perkin-Elmer DSC 1700 thermal analyzer. Disc samples were loaded into a DSC cell at room temperature and equilibrated for a few minutes. The heating rate was $10{ }^{\circ} \mathrm{C} /$ min from 25 to $550{ }^{\circ} \mathrm{C}$. Dry pure nitrogen was purged through the cell at the rate of $55 \mathrm{~mL} / \mathrm{min}$ to avoid oxidation. The data for all the DSC runs were recorded in the instrument memory. At the last two samples were analyzed for each heat-treated material. Dry ball-on disk wear-testing was also performed on the plasma-spray-deposited Al-Si/SiC composites layers. During the test, friction force originating from the normal force was measured by a load-cell (strain gauge) mounted on the loading arm. The wear tests were conducted with a cemented carbide (WC-Co) ball (4.6 mm diameter) sliding against plasmasprayed coatings. The wear tests were performed in ambient air and in relative humidity ( 38 to $39 \% \mathrm{RH}$ ) and $24{ }^{\circ} \mathrm{C}$. The wear and friction tests were carried out at $5 \mathrm{~N}$ load and at the sliding speed of $0.1 \mathrm{~m} / \mathrm{s}$. Width of wear track was measured in the optical microscopy and the wear rate was measured.

\section{Results and Discussion}

The thermal plasma-spraying technique described in this study was designed to produce Al-Si alloy matrix composites reinforced with ceramic $\mathrm{SiC}$ particles to obtain homogenous particle distribution with high wear resistance.

The cross-sectional microstructures of the plasma-sprayed composites are presented in Fig. 1. As seen from the figure,
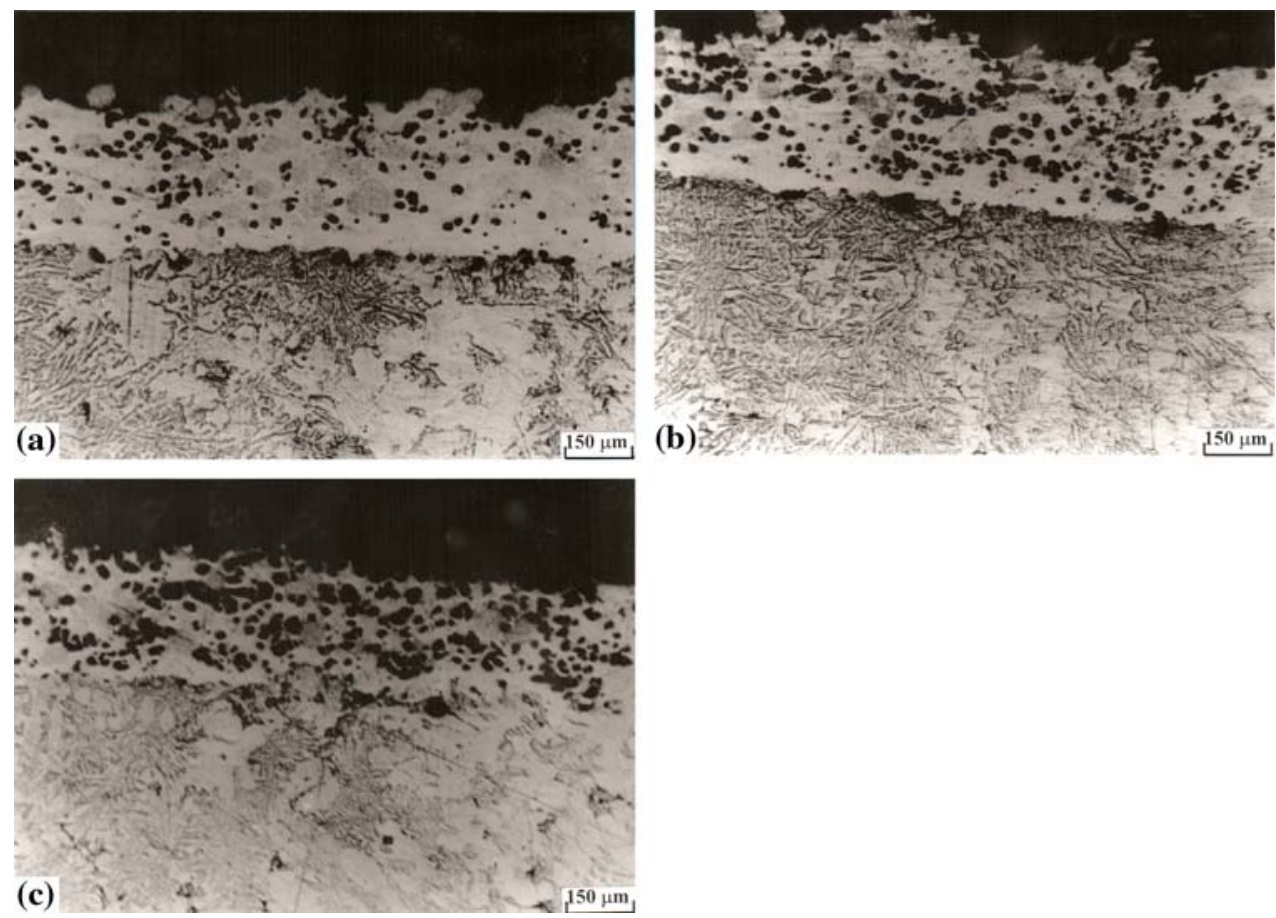

Fig. 1 Cross-sectional microstructures of the plasma-sprayed Al-Si/SiC composites: (a) 10 vol.\% $\mathrm{SiC}$, (b) 20 vol.\% $\mathrm{SiC}$, and (c) 30 vol.\% $\mathrm{SiC}$ 

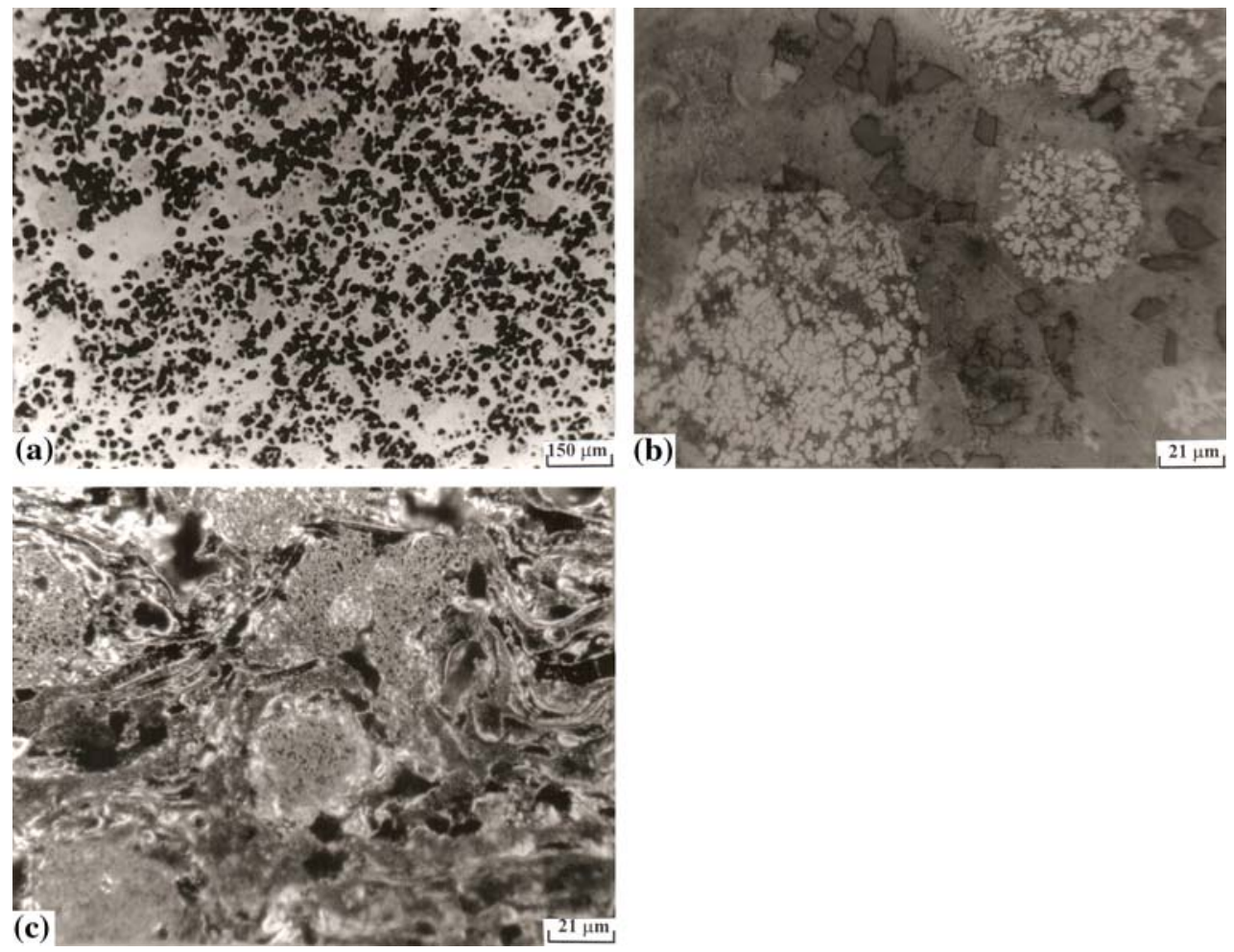

Fig. 230 vol.\% SiC-reinforced Al-Si matrix alloy: (a) particle distribution, (b) eutectic island (light image), and (c) eutectic island (dark image)

Table 1 A summary of plasma sprayed materials

\begin{tabular}{|c|c|c|c|c|c|c|c|}
\hline \multirow[b]{2}{*}{ Sample } & \multicolumn{2}{|c|}{ Particle volume percent } & \multirow{2}{*}{$\begin{array}{c}\text { Coating } \\
\text { thickness, } \mu \mathrm{m}\end{array}$} & \multirow{2}{*}{$\begin{array}{c}\text { Brinell } \\
\text { hardness }\end{array}$} & \multirow{2}{*}{$\begin{array}{c}\text { Porosity, } \\
\%\end{array}$} & \multirow{2}{*}{$\begin{array}{l}\text { Wear rate, } \\
10^{-5} \mathrm{~mm}^{3} / \mathrm{m}\end{array}$} & \multirow{2}{*}{$\begin{array}{c}\text { Friction } \\
\text { coefficient }\end{array}$} \\
\hline & Added & Measured & & & & & \\
\hline Substrate & $\ldots$ & $\ldots$ & $\ldots$ & 86.0 & $\ldots$ & $\ldots$ & $\ldots$ \\
\hline $\mathrm{Al}-\mathrm{Si}(0)$ & 0 & 0 & 427.1 & 95.5 & 6.1 & 7.95 & 0.53 \\
\hline Al-Si(10) & 10 & 7 & 375.5 & 136.6 & 5.2 & 6.84 & 0.50 \\
\hline Al-Si(20) & 20 & 17 & 370.4 & 161.6 & 6.6 & 4.85 & 0.61 \\
\hline $\mathrm{Al}-\mathrm{Si}(30)$ & 30 & 26 & 324.2 & 168.6 & 6.2 & 3.84 & 0.58 \\
\hline
\end{tabular}

only Al-Si alloy was melted by the plasma heat and the $\mathrm{SiC}$ particles remained in an unmelted state. Figure 1 also shows that the matrix microstructure of plasma-sprayed layer and the substrate is significantly different. In the gravity-cast alloy and in the substrate material, the eutectic silicon crystals have a coarse lamellar morphology, but plasma-sprayed materials reveal totally different silicon crystals. Eutectic silicon crystals are observed as equiaxed fine particles that are segregated in the form of continuous islands. Figure 2, on the other hand, shows the particle distribution (Fig. 2a) of the eutectic island in high magnification (Fig. 2b) and, dark-field image (Fig. 2c) of the 30 vol.\% SiC reinforced material. Some of the important properties of the substrate material and the plasma-sprayed $\mathrm{Al}-\mathrm{Si} / \mathrm{SiC}$ composite are summarized in Table 1 . As can be seen from the table, the particle volume fraction showed a high retention ratio after plasma-spraying on the Al-Si matrix alloy substrate. Table 1 also shows the experimental results such as Brinell Hardness, porosity, sprayed layer thickness, wear rate, and friction coefficient in the unreinforced matrix and its composites.
In recent years, the incorporation of ceramic particles into aluminum matrix composites has gained considerable interest (Ref 7). Traditional production techniques for SiC-ceramicreinforced MMCs have limited use because of a high rate of chemical interaction between $\mathrm{SiC}$ and aluminum matrix. Powder metallurgy, osprey, and thermal-spraying techniques are alternative methods of decreasing this interaction between the composite constituents (Ref 8). The microstructure of plasma-sprayed Al-Si matrix alloy and composites showed significant differences when compared with gravity-cast alloy. Plasma-sprayed Al-Si matrix alloy and composites have large amounts of primary aluminum-rich solidification structure owing to rapid solidification behavior. The eutectic phase in the sprayed materials accumulated in the form of continuous islands with very fine silicon particles. Eutectic precipitation was observed between primary $\alpha$-dendrite arms. Two facts are evident. One is that fine structures are not flake-like in form but fibrous. In brief, the structure was quench-modified. The second one is that the coupled zone in this system is asymmetric and even if silicon content is very high $\alpha$-dendrites 

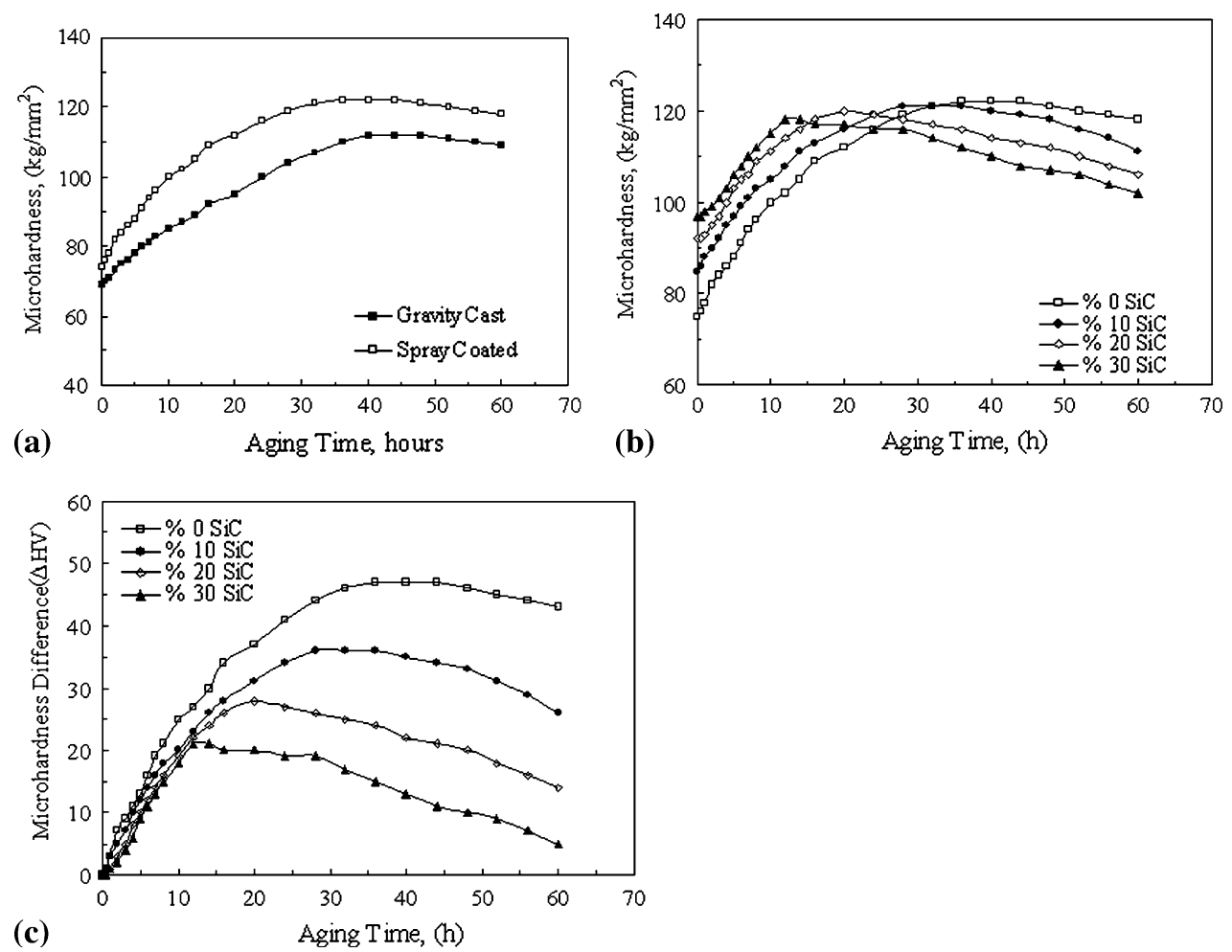

Fig. 3 (a) Vickers microhardness variation with aging time at $204{ }^{\circ} \mathrm{C}$ aging temperature in a gravity-cast and plasma-spray coating of Al-Si matrix alloys, (b) Microhardness-aging time relationship in plasma-sprayed materials, and (c) Microhardness difference with aging time

always forms. This effect has been explained for eutectic metal systems (Ref 9).

The hardness measurements obtained for the gravity-cast and plasma-spray deposited matrix alloy that were subjected to a standard T551 heat treatment are shown in Fig. 3(a). As can be clearly seen, the plasma-sprayed matrix alloy produced higher hardness values compared with the gravity-cast matrix alloy. Figure 3(b) and (c), on the other hand, presents the microhardness results of the plasma-sprayed matrix alloy and SiC-particle-reinforced composites upon aging time. Figure 3(b) shows the microhardness data taken from the primary $\alpha$-Al dendrites ( $\mathrm{SiC}$ and $\mathrm{Si}$-free regions) for the $\mathrm{SiC}$ particle-reinforced composites and shows that increasing the particle volume ratio in the Al-Si matrix alloy resulted in a decrease of the peak aging time. Figure 3(c) presents the microhardness differences obtained by aging treatment compared with as produced state (rapid-quenched or solutionized state). The microhardness increment of unreinforced matrix alloy is obtained as $47 \mathrm{HV}$ at the maximum peak-hardness time of $40 \mathrm{~h}$. Incorporation of $\mathrm{SiC}$ particles into Al-Si matrix alloy resulted in a decrease of the hardness increment and peak aging time. For example, the maximum microhardness of $30 \mathrm{vol} . \%$ SiC-particle-reinforced composite material showed $21 \mathrm{HV}$ hardness increment in $14 \mathrm{~h}$ aging time, which is the peak aging condition. This increment is $47 \mathrm{HV}$ in the unreinforced alloy at $40 \mathrm{~h}$ peak aging time.

The aging behavior of MMCs with age-hardenable alloy matrix can affect the heat-treatment behavior and the final application properties, so that it has become the subject of much interest $(\operatorname{Ref} 1,10)$. The comparison between gravity cast and plasma-sprayed Al-Si matrix alloys showed that plasmasprayed materials exhibited higher microhardness values. This was attributed to emanation of eutectic from rapid quenching. Because of the rapid quenching, high dislocation density can be obtained in the plasma-sprayed materials. Another reason is the higher solid solubility of silicon by the $\alpha$-aluminum dendrites in plasma-sprayed materials, as evidenced by the EDS and x-ray analysis. A very high rate of solidification should affect the curvature on the equilibrium diagram, and $\alpha$-dendrites dissolve much more silicon than conventionally solidified alloys. Wermolen et al. (Ref 11) have also stated that the dissolution kinetics of Si particles in an aluminum alloy can be altered with changing thermodynamic driving forces. The hardening response of the plasma-sprayed Al-Si matrix alloy containing high volume fractions of SiC particles degraded sharply, and the lowest increase in the Vickers hardness value, upon heat treatment, obtained in the $30 \mathrm{vol} \%$ SiC-contained plasmasprayed material. The results indicate that the fall in the hardening response of the composites, with increasing volume percent of the $\mathrm{SiC}$ particles, was much faster than expected. The same results have been observed in the short alumina fiberreinforced Al-Si-Cu alloys (Ref 12). In this study, the agehardening condition was kept constant for the matrix alloy and the plasma-sprayed composites. It may be possible to increase, or even to do away with the peak in hardness by exploration of hardening conditions for each $\mathrm{SiC}$ particle volume, as Thomas and King (Ref 13) showed for SiCp-reinforced 2124 Al alloy. T551 standard heat-treatment studies proved that plasmasprayed matrix alloy was more suitable for aging treatment than gravity-cast alloy, which has almost the same chemical composition as sprayed Al-Si matrix alloy. Because of the very high rate of solidification (i.e., $10^{4}{ }^{\circ} \mathrm{C} / \mathrm{s}$ ) by plasma process, the Al-Si matrix alloy remained nearly in the solid solution state. This resulted in more effective precipitation reaction than 
gravity-cast Al-Si matrix alloy. It is reported by Zhang et al. (Ref 1) and Thomas and King (Ref 13) that in MMCs with heat-treatable matrix the already-existing intermetallic phases could not be completely dissolved into matrix during solutionizing treatment. After quenching from the solutionizing temperature, therefore, the amount of precipitated phase was reduced. In plasma-sprayed matrix, the hardening at higher cooling rates is because of vacancy/GP zones and dislocations. As the cooling rate increases, the amount of quenched-in vacancies necessary for GP-zone formation also increases. Because of the high cooling rates, the amount of quenched-in vacancies available for precipitation and solute strengthening is increased in the plasma-sprayed matrix alloy.

The DSC traces of the unreinforced Al-Si matrix and the SiC-particle-reinforced composite materials are shown in Fig. 4. For comparison purposes, results from DSC scans of the gravity-cast Al-Si matrix alloy and plasma-sprayed Al-Si matrix alloy are presented in Fig. 4(a). The DSC traces of matrix alloys produced by gravity-cast and plasma-spraying do not exhibit significant differences depending on the GP-zone formation/dissolution and precipitate formation/dissolution temperatures. The curve of Al-Si matrix alloys shows the exothermic reaction between 45 to $47^{\circ} \mathrm{C}$ and 137 to $140{ }^{\circ} \mathrm{C}$ owing to the formation of GP zones; the endothermic between 137 to $140{ }^{\circ} \mathrm{C}$ and 238 to $240{ }^{\circ} \mathrm{C}$ owing to the dissolution of GP zones; the exothermic between 238 to $240{ }^{\circ} \mathrm{C}$ and 361 to $363{ }^{\circ} \mathrm{C}$ owing to formation of precipitates; and the endothermic between 361 to $363{ }^{\circ} \mathrm{C}$ and 481 to $486{ }^{\circ} \mathrm{C}$ owing to dissolution of precipitates. The DSC curve for gravity-cast matrix material, however, exhibits smaller amounts of GP-zone formation compared with plasma-sprayed matrix alloy. From the DCS curves, another obvious difference to note is that the plasmasprayed matrix exhibits two precipitate peaks (marked A and B), whereas the gravity-cast matrix shows only a single precipitate peak (marked B). Figure 4(b) shows the DSC curves for the plasma-sprayed Al-Si matrix reinforced with $\mathrm{SiC}$ particles. Figure 4(b) reveals that introducing $\mathrm{SiC}$ particles into the Al-Si matrix alloy results in a suppression of GP-zone formation. Among the SiC particle composites studied only the 10 vol.\% SiC-reinforced Al-Si matrix alloy shows a small GP-zone formation peak. Excess $\mathrm{SiC}$ particles result in the disappearance of GP zones in the matrix. As can be seen from Fig. 4(b), reinforcing the Al-Si matrix alloy by $\mathrm{SiC}$ particles causes acceleration of precipitate formation. The peaks identified in Fig. 4(b) and the corresponding temperatures are presented in Table 2.

The hardness versus aging time and the DSC curves show similar trends between the gravity-cast and plasma-sprayed matrix materials. There is no clear indication that the time to peak hardness is affected by quench rate. Plasma-sprayed matrix alloy produced more GP zones when compared with gravity-cast material. Increasing the amount of GP zones in the plasma-sprayed matrix resulted in a higher amount of precipitates in the plasma-sprayed matrix material. Couper and Polmear (Ref 14) have also suggested that increasing the amount of quenched-in vacancies facilitates nucleation of precipitates during aging. It can be seen that the age-hardening rate of Al-Si matrix material is affected by the presence of ceramic particles.

Plasma-sprayed Al-Si matrix that is reinforced with $\mathrm{SiC}$ particles does not show GP-zone formation, except that 10 vol.\% SiC-reinforced composite revealed a small amount of GP zone area. In the composites, dislocations and matrixparticle interfaces serve as vacancy sinks, which inhibit GP-zone formation, as also stated by several authors (Ref 8, 13, 15). Since a large amount of dislocations is formed in the composite rather
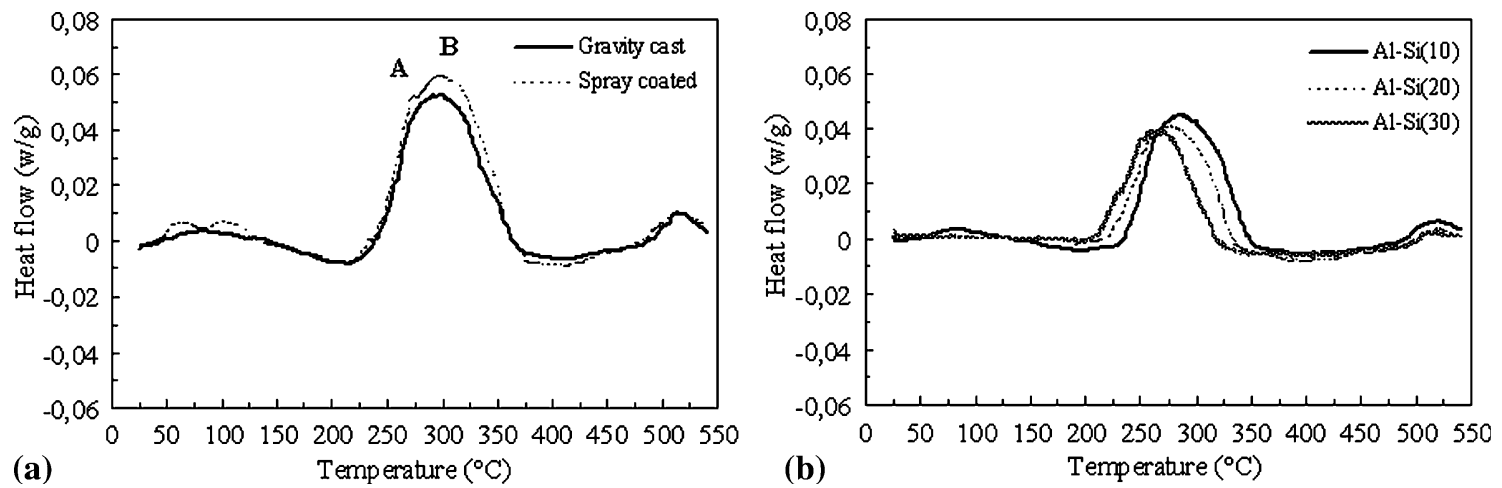

Fig. 4 Results of DSC analysis: (a) Al-Si matrix alloys and (b) Plasma-sprayed Al-Si/SiC composites

Table 2 Analysis of DSC scans of matrix material and composites

\begin{tabular}{|c|c|c|c|c|c|}
\hline \multirow[b]{2}{*}{ Material } & \multicolumn{5}{|c|}{ Temperature of the peaks, ${ }^{\circ} \mathrm{C}$} \\
\hline & $\begin{array}{l}\text { GP-zone } \\
\text { formation }\end{array}$ & $\begin{array}{c}\text { GP-zone } \\
\text { dissolution }\end{array}$ & $\begin{array}{l}\text { Precipitate } \\
\text { formation }\end{array}$ & $\begin{array}{l}\text { Peak for } \\
\text { precipitate }\end{array}$ & $\begin{array}{l}\text { Precipitate } \\
\text { dissolution }\end{array}$ \\
\hline Gravity-cast LM 13 & 45 & 140 & 240 & 297 & 363 \\
\hline Plasma-sprayed LM 13 & 47 & 137 & 238 & 299 & 361 \\
\hline $\mathrm{LM}+10$ vol. $\% \mathrm{SiC}$ & 52 & 132 & 235 & 288 & 348 \\
\hline $\mathrm{LM}+20$ vol. $\% \mathrm{SiC}$ & $\ldots$ & $\ldots$ & 220 & 277 & 331 \\
\hline $\mathrm{LM}+30$ vol. $\% \mathrm{SiC}$ & $\cdots$ & $\cdots$ & 205 & 262 & 318 \\
\hline
\end{tabular}


than quenched-in vacancies and the GP zones, the time required to attain peak aging is decreased when compared with unreinforced alloy. Hardness and DSC curves of the composites indicated that particles accelerated the aging kinetics of the Al-Si matrix material.

The solid solubility of $\mathrm{Si}$ in $\mathrm{Al}$ is approximately $1.9 \mathrm{wt} . \%$ at $570{ }^{\circ} \mathrm{C}$. In equilibrium state, the solid solubility of $\mathrm{Si}$ in $\mathrm{Al}$ is omitted. Increasing the cooling rate, however, promotes solubility for solid solution, as is well known. In this study, the EDS analysis taken from the primary $\alpha$-aluminum dendrites revealed that in plasma-sprayed matrix alloys, more $\mathrm{Si}$ was dissolved in the aluminum matrix compared with Si solubility in the gravity-cast matrix alloy. The EDS analysis showed that approximately $0.5 \mathrm{wt} . \% \mathrm{Si}$ was detected in $\alpha$-Al primary phase whereas in plasma-sprayed unreinforced alloy $\mathrm{Si}$ content was measured as $1.1 \mathrm{wt} \%$. Similar analysis is valid for $\mathrm{Cu}$ dissolution. Since an increase was observed in the solid solubility of $\mathrm{Si}$ in the $\alpha$-Al primary phases, $\mathrm{x}$-ray analysis was carried out to reveal enough evidence by obtaining lattice parameters. The stored gravity-cast and plasma-sprayed matrix materials at refrigerator (at $-15^{\circ} \mathrm{C}$ ) were $\mathrm{x}$-ray analyzed and the obtained lattice parameters are summarized in Table 3 . It is clearly seen from the table that plasma-sprayed matrix alloy produced smaller lattice parameters than those of gravity-cast matrix alloy.

Figure 5 shows the x-ray diffraction patterns for the gravitycast and plasma-sprayed Al-Si matrix alloy after $30 \mathrm{~h}$ aging at $204{ }^{\circ} \mathrm{C}$. The gravity-cast material shows only a $\mathrm{S}^{\prime} \mathrm{Al}_{2} \mathrm{CuMg}$ precipitate (pattern a). It can be seen from the $\mathrm{x}$-ray patterns of the plasma-sprayed matrix material that an additional precipitated phase in the $\mathrm{Mg}_{2} \mathrm{Si}$ type is found in the matrix (pattern b).

In this study, the plasma-spraying process caused to retain more alloying elements in the matrix and eliminated the adverse effects emanating from composite matrices. Moreover, a very high rate of solidification reaction eliminated

Table 3 Lattice parameters in the gravity cast and plasma spray produced matrix materials

\begin{tabular}{lcccc}
\hline Matrix material & $\mathbf{2 \theta}$ & $\boldsymbol{d}, \AA$ & $\boldsymbol{h k l}$ & $\boldsymbol{a}, \AA$ \\
\hline Gravity cast & 38.40 & 2.3421 & 111 & 4.0567 \\
& 44.64 & 2.0281 & 200 & 4.0563 \\
Plasma sprayed & 65.02 & 1.4331 & 220 & 4.0536 \\
& 38.46 & 2.3386 & 111 & 4.0510 \\
& 44.72 & 2.0247 & 200 & 4.0494 \\
& 65.11 & 1.4316 & 220 & 4.0492 \\
\hline
\end{tabular}

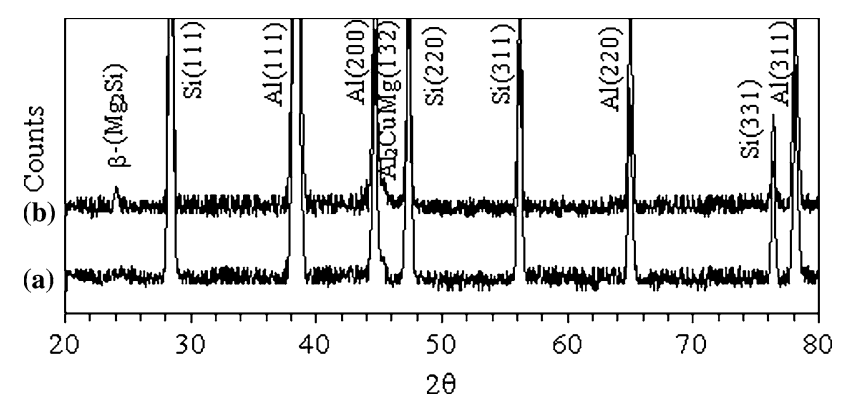

Fig. 5 XRD patterns for $30 \mathrm{~h}$ aged materials at $204{ }^{\circ} \mathrm{C}$ : (a) $30 \mathrm{vol} . \%$ $\mathrm{SiC}$ particle contained Al-Si matrix alloys and (b) Unreinforced Al-Si matrix alloy solutionizing of the matrix, and this is another attractive feature to decrease the cost of the alloy production. The x-ray analyses performed for Al-Si plasma-sprayed matrix alloy and the plasma-sprayed SiC-containing composites have shown that thermal treatment yields the formation of $\beta$ and $S^{\prime}$-type precipitates for both matrix alloy and its composites, whereas gravity-cast matrix material shows only $\mathrm{S}^{\prime}$-type precipitates. This was attributed to more Si dissolution owing to a very high rate of solidification in the plasma-sprayed matrix and its composites. Additional $\beta^{\prime}\left(\mathrm{Mg}_{2} \mathrm{Si}\right)$ precipitates therefore were formed in the plasma-sprayed materials.

Moreover, as-sprayed Brinell hardness values are listed in the table, as well. After the ball-on disk wear-testing with $0.5 \mathrm{~m} / \mathrm{s}$ sliding speed at $5 \mathrm{~N}$ applied normal load at the dry condition in air, wear resistance of the SiC-particle-distributed $\mathrm{Al}-\mathrm{Si}$ matrix alloy was also increased almost linearly with increasing $\mathrm{SiC}$ particle content, but a small increment was detected in the friction coefficient values.

In accordance with the high cooling rate, the wear resistance values and the coefficient of friction values were seen to be quite satisfactory for plasma-sprayed materials (shown in Table 1). For the composites, SiC particles have higher hardness and wear resistance than the matrix. During the wear process, the matrix material will be worn off rapidly, and the homogenously distributed SiC particles will bear the load, which will retard the wear process and result in a finer wear trace on the surface. As obtained from the wear results, increasing particle content in the plasma-sprayed $\mathrm{Al}-\mathrm{Si} / \mathrm{SiC}$ composite resulted in a decrease in the wear rates. As also stated by Ghost et al. (Ref 16) plasma-spraying process can obtain very homogeneous particle distribution without clustering even at the 50 to $60 \mathrm{vol} \%$ particle addition, and this decreases the wear rate almost linearly with increasing particle volume. Wielage et al. (Ref 17), consistent with this study, found that thermal plasma-spraying has a main advantage in terms of superior tribological properties of materials, and thus this coating structure opens a wide field of technological applications.

\section{Conclusions}

1. The Al-Si matrix alloy containing SiC-ceramic particles can be produced by plasma-spray method on the metal substrates for high wear-resistance applications.

2. Very high rate of solidification after plasma-spraying increased the solid solubility of the alloying elements in the matrix, and this caused an increase in the hardness compared with gravity-cast material.

3. Effective solid solubility by plasma-spraying process can eliminate the solutionizing process and obtain higher hardness for the matrix when compared with traditional casting processes.

4. Incorporation of $\mathrm{SiC}$ particles into $\mathrm{Al}-\mathrm{Si}$ matrix alloy resulted in changed precipitation kinetics. Increasing particle volume content in the matrix accelerated precipitation reaction and caused over-aging when compared with unreinforced plasma-sprayed matrix.

5. Although having an approximate $6 \%$ porosity level, the wear resistance increases with the addition of $\mathrm{SiC}$ particles, with a small amount of increment in the coefficient of friction. 


\section{References}

1. J.S. Zhang, X.J. Liu, and H. Cui, Microstructure and Properties of Spray-Deposited $2014+15$ vol. pct SiC Particulate-Reinforced Metal Matrix Composite, Metall. Trans., 1997, 28A, p 1261-1269

2. A.R.E. Singer, Metal Matrix Composites made by Spray Forming, Mater. Sci. Eng., 1991, A135, p 13-17

3. S. Dallaire and J.G. Legoux, High-Temperature Tribological Properties of Plasma-Sprayed Metallic Coatings Containing Ceramic Particles, J. Therm. Spray Technol., 1996, 5, p 43-48

4. M. Gui, S.B. Kang, and K. Euh, Microstructure Characteristics of SiC Particle-Reinforced Aluminum Matrix Composites by Plasma Spraying, J. Therm. Spray Technol., 2004, 13, p 537-543

5. M. Gui and S.B. Kang, Dry Sliding Wear Behavior of Plasma-Sprayed Aluminum Hybrid Composite Coatings, Metall. Trans., 2001, 32A, p 2383-2392

6. M. Gui, S.B. Kang, and K. Euh, Influence of Spraying Conditions on Microstructures of Al-SiCp Composites by Plasma Spraying, Metall. Trans., 2005, 36A, p 2471-2480

7. S. Su, X. Liang, A. Moran, and E.J. Lavernia, Solidification Behavior of an Al-6Si Alloy During Spray Atomization and Deposition, Int. J. Rapid Solid., 1994, 8(3), p 161-177

8. E.J. Lavernia, J.D. Ayers, and T.S. Srivatsan, Rapid Solidification Processing with Specific Application to Aluminum-Alloys, Int. Mater. Rev., 1992, 37, p 1-37
9. O.A. Atasoy, F. Yilmaz, and R. Elliott, Growth Structures in Aluminium-Silicon Alloys I. The Coupled Zone, J. Cryst. Growth, 1984, 66, p 137-146

10. Y. Song and T.N. Baker, Accelerated Aging Processes in Ceramic Reinforced AA-6061 Composites, Mater. Sci. Technol., 1994, 10, p 406-413

11. F.J. Wermolen, H.M. Slabbekoorn, and S. Van De Zwang, The Apparent Activation Energy for the Dissolution of Spherical Si-Particles in AlSi-Alloys, Mater. Sci. Eng., 1997, A231, p 80-89

12. H. Akbulut, M. Durman, and F. Yilmaz, A Comparison of As-Cast and Heat-Treated Properties in Short Fiber Reinforced Al-Si Piston Alloys, Scr. Mater, 1997, 36, p 835

13. M.P. Thomas and J.E. King, Effect of Thermal and Mechanical Processing on Tensile Properties of Powder Formed 2124 Aluminium and 2124 AlSiCp Metal Matrix Composites, Mater. Sci. Technol., 1993, 9, p 742-753

14. M.J. Couper and I.J. Polmear, Quench Sensitivity in Some Rapidly Solidified Aluminum-Alloys, J. Mater. Sci. Lett., 1987, 6, p 922-925

15. N.A. Oguocha, M. Radjabi, and S. Yannacopoulso, The Effect of Cooling Rate on the Quench Sensitivity of $2618 \mathrm{Al} / \mathrm{Al}_{2} \mathrm{O}_{3} \mathrm{MMC}$, J. Mater. Sci., 2000, 35, p 5629-5634

16. K. Ghost, T. Troczynski, and A.C.D. Chaklader, Aluminum-Silicon Carbide Coatings by Plasma Spraying, J. Therm. Spray Technol., 1998, 7, p 78-86

17. B. Wielage, S. Steinhauser, T. Schnick, and D. Nickelmann, Characterization of the Wear Behavior of Thermal Sprayed Coatings, J. Therm. Spray Technol., 1999, 8, p 553-558 